\title{
Surgical rehabilitation of patients with atypical anatomical and functional states after radical organ-preserving operations for non-tumour colon diseases
}

\begin{abstract}
The aim of the work: to demonstrate modern possibilities and ways of providing rehabilitation of patients after radical surgical treatment of non-tumour colon diseases with available non-typical anatomical and functional states.

Materials and Methods. The system of surgical rehabilitation measures was developed, which was used in 32 patients with available atypical anatomical and functional states after radical organ-preserving operations in non-tumour colon diseases. They are aimed at implementing sufficiently radical, reconstruction and restoration operations, forecasting and preventing postoperative complications, improving functional results, reducing the incidence and severity of severe forms of diarrhea and postcolectomy syndromes. Results and Discussion. In 2 (6.3\%) patients there were complications due to the implementation of reconstruction and restoration stage of surgical intervention. They led to the necessity of extirpation of the anal canal fistula, removal of ileoendoanal anastomosis, and the formation of a lifelong ileostomy. In 30 (93.7\%) patients, favourable functional results were obtained, and a significant level of surgical and social work rehabilitation was achieved. A significant level of rehabilitation of operated patients was achieved through the implementation of sufficiently radical and developed reconstruction and restoration operations that prevented the relapse of the disease, the emergence of pathological conditions caused by the removal of the large intestine; prognostication and purposeful prevention of severe postoperative complications, stage monitoring of the condition of operated patients.
\end{abstract}

Key words: surgical rehabilitation; non-tumour colon diseases; reconstruction and rehabilitation operations.

Introduction. Surgical treatment of patients with severe non-tumour diseases of the colon involves not only the elimination of the underlying disease and its complications, but also the creation of proper conditions for the return to society of a person sufficiently adapted to the conditions of social life. In this regard, the rehabilitation of patients which main measures should be aimed at preventing relapse of the disease, the emergence of postoperative complications, ensuring sufficiently favourable functional results, and severe forms of the consequences of surgical treatment - diarrhea and postcollectomic syndromes - becomes important. For the successful implementation of these provisions, it is necessary to improve the methods of diagnosis of diseases, surgical treatment, monitoring the state of operated patients during their life, correction of the revealed irregularities.

The aim of the work: to demonstrate modern possibilities and ways of providing rehabilitation of patients after radical surgical treatment of non-tumour colon diseases with available non-typical anatomical and functional states.

Materials and Methods. Under the concept of surgical rehabilitation we understand consistent implementation of the system of organizational and surgical measures aimed at implementing a sufficiently radical and reconstruction and restoration stages of surgical intervention, prediction and targeted prevention of postoperative complications, staged monitoring of patients in the postoperative period, providing correction of detected pathological conditions.

In non-tumour colon diseases, which include ulcerative colitis, Crohn's disease of the colon with total impression, familial adenomatous polyposis is sufficiently radical and at the same time, organ-preserving operations in most cases are colectomy, ultralow front resection, mucosectomy of the surgical anal canal. After the mentioned, sufficiently large radical surgery, each patient needs appropriate rehabilitation, the need for which is due to anatomical changes of the intestinal canal and irregulatities of its function.

In addition, in the surgical treatment of non-tumour colon diseases, there are often unusual anatomical and functional conditions that create additional technical difficulties in the reconstruction and restoration stage of surgical treatment, providing favourable functional results, increase the risk of postoperative complications and, accordingly, have a negative impact on quality of rehabilitation. These states include: reduction of the length of the ileum as a result of its resection when the pathological process affects it, the short aspiration of the small intestine, the diffuse type of the architectonics of the upper mesenteric artery, the peculiarities of the design of the pelvic small intestine reservoir, the formation of which requires the use of more than the standard reservoirs of the ileum, functions of 
the small intestine, in particular, the presence of an "irritable small intestine syndrome." Therefore, in the surgical treatment of non-tumour colon diseases there is a well-grounded risk of unsatisfactory results due to the occurrence of pathological syndromes of diarrhea and postcolectomy as a result of the removal of all anatomical units of the colon with the resolution of the terminal ileum section, the risk of frequent postoperative complications, in particular, the failure of sutures of anastomosis, peritonitis, pelvic cellulitis, stricture of anastomosis, as well as insufficient functionality of the capabilities of known methods of surgical rehabilitation, in particular, the classical methods of forming pelvic small intestine reservoirs, reservoir and anal anastomosis.

In order to address the problem of rehabilitation in this category of operated patients, it is necessary to use a complex of organizational and therapeutic and prophylactic measures that consist in performing reconstruction and restoration operations with the formation of anatomical structures capable of compensating for the function of the removed organs; correction of violations of water-electrolyte and protein-energy exchanges; the psychological reorganization of the patient aimed at awareness and perception of the existing irreversible anatomical changes in the digestive canal caused by their new lifestyle. In such a situation, the patient needs to put some effort, aimed at adapting to the functional features of the digestive canal, the conditions of social activity and labour.

When implementing rehabilitation measures, it is important to use methods for monitoring and assessing the effectiveness of rehabilitation, in particular, the method of stage monitoring, which involves a patient survey through 1, 3, 6, 12 months, in the future 1-2 times a year depending on the nature of the main disease, peculiarities of the radical and reconstruction and restoration stage of surgical treatment with the aim of:

- defining the results of the radical stage of surgical treatment for timely diagnosis of a possible relapse of the disease;

- establishment of terms for the implementation of the following stages of surgical treatment, in particular, the secondary reconstruction and reduction operation, "closure" of the protective ileostomy;

- evaluation of the features of healing of the formed pelvic small intestine reservoir, ileoendoanal anastomosis;

- evaluation of functional results: features of defecation, anal holding, control of transit of contrast medium in the small intestine;

- diagnosis and treatment of complications in the late postoperative period: stricture of anastomosis, fistula, postoperative hernia;
- psychological adaptation of patients to qualitatively new conditions of life, physical activity, choice of work activity;

- analysis and evaluation of the results of newly developed methods of rehabilitation.

Evaluation of the effectiveness of surgical rehabilitation was carried out in 32 operated patients for serious non-tumour colon diseases: ulcerative colitis - 14 (43.8\%), Crohn's colon disease - 8 (25.0\%), familial adenomatous polyposis - 10 (31.2\%) for the period from 2008 to 2017. There were 18 (56.2 \%) male patients, female -14 (43.8\%). The age of operated patients was 18-35 years old. Concomitant diseases: diabetes mellitus, obesity, varicose disease of the superficial veins of the lower extremities, peptic ulcer of the duodenum in the remission stage, essential thrombocytopenia was detected in 7 (21.7\%) patients.

The radical stage of the surgical intervention consisted of the execution of colectomy, ultra-low front resection of the rectum, mucosectomy of the surgical anal canal - in 21 (65.6 \%) patients. In the remaining 11 (34.4 \%) patients, in addition to colectomy with ultra-low front resection of the rectum of the mucosectomy of the surgical anal canal, resection of the terminal ileum section with the length from 15 to $70 \mathrm{~cm}$ was performed in connection with terminal ileitis in Crohn's disease and ulcerative colitis.

The reconstruction and rehabilitation stage of surgical intervention consisted in the formation of a pelvic small intestine reservoir and ileoendoanal anastomosis.

In patients with atypical anatomical and functional states, developed reconstruction and restoration operations of a new type were used: the method of pelvic small intestine reservoir, ileoendoanal anastomosis, methods of mobilization and placement of a small intestine transplant as the main factors aimed at improving functional results and rehabilitation of patients.

The developed method of pelvic small intestine reservoir of type [1] using two factors of delay in moving the content of the small intestine was used in 14 patients, of whom 11 at the time of removal of all anatomical parts of the colon and resection of the terminal ileum section, and 3 - in the presence of an "irritable small intestine syndrome" when performing a secondary reconstruction and reduction operation.

The author's method of ileoendoanal anastomosis [2], which foresaw the comparison of the ileum gland segments and demuccated anal canal surfaces with homogeneous tissues - submucosal bases of these segments, was formed in all 32 operated patients.

The developed method of mobilization of the small intestine translpant [3] by crossing the peritoneal transitional sheet alon the perimeter of the root of the erythema of the small intestine was used - in 21 (65.6 \%) patients with short erythema of the small intestine and scattered type of architectonics of 
the upper erythema artery. The method of dislocation of the small intestine transplant [4] by crossing the marginal vascular arcade and its direct vessels was used in 11 (34.4\%) patients after additional removal of the terminal ileum section affected by the pathological process. Primary reconstruction and rehabilitation operations were performed in 25 (78.1 $\%)$ patients, secondary - in 7 (21.7 \%).

In the preoperative period, each patient with the planned implementation of the reconstructiion and restoration stage of the surgical intervention performed the prognosis of the most severe and widespread complications: the failure of the anastomosis sutures, peritonitis, intraoperative damage of the abdominal cavity and retroperitoneal space, bleeding, adhesion obstruction of the small intestine. On the basis of established risk factors, appropriate preventive measures were taken. The aforementioned approach to the prevention of postoperative complications contributed to a significant reduction in the number of their occurrence.

Results and Discussion. In the early postoperative period, complications occurred in 4 (12.5\%) patients: abscess of the pelvic cavity 1 , suppuration of the surgical wound -1 , pneumonia -1 , acute pyelocystitis - 1 . Treatment was performed in accordance with generally accepted standards. These complications due to effective treatment did not significantly affect the quality of rehabilitation of operated patients. In the late postoperative period, due to phase monitoring, the small intestine and vaginal fistula was diagnosed promptly in 1 patient in 1 month, and an ischemic reservoir - in 1 patient after 14 months after the completion of surgical treatment. The mentioned patients were extirpated by the anal canal fistula along with the ileoendoanal anastomosis, the formation of lifelong ileostomy by the Brooke's method. Subsequently, the rehabilitation of these patients was to maximize adaptation to the conditions of the functioning ileostomy.

Evaluation of rehabilitation of operated patients was performed 1 year after the completion of all stages of surgical treatment, during the period of relative stabilization of adaptation processes to new conditions of the functioning of the digestive canal, due to the implementation of radical and reconstruction and restoration stages of surgical intervention. The evalution of the quality of rehabilitation was carried out in accordance with the following criteria: the state of digestive function, absorption, defecation, anal holding, presence and degree of severity of diarrhea, postcollectomic syndromes, implementation of social programs, in particular, education, employment, creation or preservation of the family, birth and parenting.
During this observation period, there was a significant improvement in functional results, in particular, in the function of intestinal digestion and absorption. This was confirmed by the results of a coprological study: the available gruel-like, often thick consistency of chyme, insignificant content of starch, food fibers, neutral fat in it. An important integral indicator of digestion and absorption was the increase in body weight of operated patients, an average of $(14.3 \pm 2.7) \mathrm{kg}$. Indicators of the function of defecation and anal holding were largely similar to the corresponding indicators of a healthy person. In the vast majority of cases, the frequency of defecations was 2-4 times during the day. The daily amount of chyme during defecation ranged from 300350 grams of gruel-like or thick consistency, which also indicated the favourable flow of intestinal digestion and absorption processes.

Based on a survey among operated patients, signs of anal incontinence in $93.7 \%$ of patients did not occur. The index of anal sphincterometry in the state of physiological rest was $(43.4 \pm 3.8) \mathrm{mm} \mathrm{Hg}$, in the state of volitional contraction of rectal sphincter

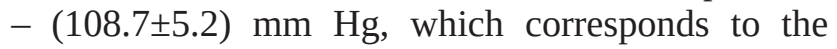
lower limit of its physiological value and confirms the presence of satisfactory anal function.

The results of controlled laboratory tests: clinical, biochemical analysis of blood, coagulogram, in most cases, corresponded to the state of physiological norm and indicated in operated patients for compensation of metabolic processes.

Quite satisfactory indices of the functions of intestinal digestion, absorption, defecation, anal holding caused the absence of diarrhea syndrome, a significant decrease in the severity of postcolectomy syndrome. The stage 1 of postcolectomy syndrome was established in $93.7 \%$ of operated patients, the stage 2 - in $6.3 \%$. All of them were sufficiently adapted to the conditions of modern society, occupied an active life position, did not need medical treatment, aimed at correction of homeostasis.

The satisfactory results of surgical rehabilitation provided for favourable conditions of proper social and labour rehabilitation of operated patients, the results of which are presented in Table 1.

Table 1. Results of Social and Labour Rehabilitation

\begin{tabular}{||l|l|l||}
\hline \multicolumn{1}{|c|}{ Indicator } & absc. & $\%$ \\
\hline Labour activity according to the specialty & 12 & 37.5 \\
\hline Education, getting a specialty & 4 & 12.5 \\
\hline Individual labour activities & 9 & 28.1 \\
\hline Sustainable disability & 2 & 6.3 \\
\hline Creating a family & 5 & 15.6 \\
\hline Birth and parenting & 6 & 18.7 \\
\hline
\end{tabular}


The data presented in the table indicate a rather high level of social and labour rehabilitation of operated patients. A significant number of them - 12 (37.5\%) returned to perform their previous professional duties. These are the specialists whose work is related to intellectual activity or the provision of services. 3 patients finished their education and received a specialty, 1 continues to study at a higher educational institution. A significant number of patients -9 (28.1\%) are engaged in individual labour activities, which do not require a strict workingday schedule, high discipline of work and excessive physical activity. Only 2 patients did not resume labour activity. They were subjected to extirpation of the anal fistula and ileoendoanal anastomosis, the formation of a lifelong ileostomy as a result of postoperative complications. By the decision of the medical and social expert commission they were found to have group 2 disability.

It should be noted that in the period leading up to surgical interventions, 11 (34.3\%) patients were married. In two families in the postoperative period, children were born, in one of them - two. Only 1 marriage was terminated due to the consequences of surgical treatment. After surgical treatment, 5 (15.6 \%) operated patients married, created their own families. In 4 created families children were also born. Two were born in one of them.

Solving the issues of rehabilitation of patients with severe non-tumour colon diseases is extremely important in view of the fact that the contingent of these patients - young people who seek to solve in their lives a number of plans and programs aimed at maximizing self-realization in the biological and social aspects. In most cases it is important for these patients to complete their studies, get the desired specialty, realize their creative or only labour potential, create a family, give birth and raise a child, be a full-value and valuable member of society.

\section{LITERATURE}

1. Рішення про видачу деклараційного патенту на корисну модель 20036/3У/18, Україна. МПК А 61 В 17/00. Спосіб формування тонкокишкового тазового резервуара / Мельник В. М., Пойда О. І., Абдулрахман Абдул Кадір (Україна); заявник і патентовласник Національний медичний університет імені О. О. Богомольця.- u 2018 02861; заявл. 21.03.18; видано 18.07.18.

2. Патент 127364 Україна. МПК А 61 В 17/00. Спосіб ілеоендоанального анастомозу / Мельник В. М., Пойда О. І., Абулрахман Абдул Кадір (Україна); заявник і патентовласник Національний медичний університет імені О. О. Богомольця. U 201802283; заявл. 5.03.2018; опубл. 25.07.2018, Бюл. № 14.
The sufficiently high level of rehabilitation of operated patients was achieved through adherence to the exhausted standards of diagnosis and treatment of severe non-tumour colon diseases, the implementation of radical surgical interventions that minimized the risk of recurrence of the disease, reconstruction and rehabilitation operations, which provided sufficiently favourable functional results and prevented the occurrence of pathological conditions caused by removal of the large intestine, prediction and targeted prevention with serious postoperative complications, as well as by stage monitoring of operated patients, which provided timely diagnosis of pathological conditions and their correction. It should be noted that the rehabilitation of patients operated for serious nontumour colon diseases is a complicated, responsible and lengthy process. It begins with the diagnosis of the disease and the surgical treatment of the patient and should extend throughout their life. The ultimate goal of this process is the return of a full-value, sufficiently rehabilitated, disabled citizen to the society.

Conclusions. 1. Surgical rehabilitation of patients operated for serious non-tumour colon diseases is a complex of organizational and therapeutic and prophylactic means aimed at returning to a society of a citizen sufficiently adapted to the conditions of modern society.

2. Surgical rehabilitation of patients with atypical anatomical and functional states in the radical surgical treatment of non-tumour colon diseases requires further improvement of surgical treatment methods and lifelong monitoring of the condition of operated patients.

3. Performing sufficiently radical surgical operations, developing new reconstruction and rehabilitation operations for existing non-typical anatomical and functional states contributed to the provision of favourable functional results, a significant level of surgical and social and labour rehabilitation in $93.7 \%$ of patients.

3. Патент 71956 Україна. МПК А 61 В 17/00. Спосіб дислокації тонкокишкового трансплантата у порожнину малого таза. / Мельник В. М., Пойда О. І. (Україна); заявник і патентовласник Національний медичний університет імені О.О. Богомольця. - u 201203875; заявл. 30.03.12; опубл. 25.07.12, Бюл. № 14.

4. Патент 128180 Україна. МПК А 61 В 17/00. Спосіб мобілізації тонкокишкового трансплантата / Мельник В. М., Пойда О. І., Абдулрахман Абдул Кадір (Україна); заявник і патентовласник Національний медичний університет імені О. О. Богомольця.- U 201802253; заявл. 5.03.18; опубл. 10.09.18, Бюл. № 17 


\section{REFERENCES}

1. Decision on Issuing a Declarative Patent for a Utility Model 20036/ 3У/18, Ukraine. MПК А 61 В 17/00. Method of Formation of Small Intestine Pelvic Reservoir. V.M. Melnyk, O.I. Poida, Abulrakhman Abdul Kadir. (Ukraine). - National Medical University named after O.O. Bohomolets. u 2018 02861- Rep. on 21.03.2018. Issued on 18.07.2018 [in Ukrainian].

2. Patent 127364 Ukraine. A 61 B 17/00. Method of Ileoendoanal Anastomosis. V.M. Melnyk, O.I. Poida, Abulrakhman Abdul Kadir. (Ukraine). National Medical University named after O.O. Bohomolets U 201802283 Rep. on 5.03.2018; Publ. on 25.07.2018. Rep. N 14 [in Ukrainian].
3. Patent 71956 Ukraine. A 61 B 17/00. Method of Dislocation of Dmall Intestine Transplant into the Small Pelvic Cavity. /V.M. Melnyk, O.I. Poida, Abulrakhman Abdul Kadir. National Medical University named after O.O. Bohomolets. u201203875. Rep. on 30.03.12; Publ. on 25.07.12. Rep. N. 14 [in Ukrainian].

4. Patent 128180 Ukraine. A 61 B 17/00. Method of Mobilization of Small Intestine Transplant. V.M. Melnyk, O.I. Poida, Abulrakhman Abdul Kadir. (Ukraine). - National Medical University named after O.O. Bohomolets U 201802253 - Rep. on 5.03.2018; Publ. on 10.09.2018. Rep. N. 17 [in Ukrainian].

Отримано 16.07.2018

Електронна адреса для листування: alzaatah@yahoo.com

В. М. МЕЛЬНИК, О. І. ПОЙДА, АБДУЛРАХМАН АБДУЛ КАДІР

Національний медичний університет імені О. О. Богомольця

\title{
ХІРУРГІЧНА РЕАБІЛІТАЦІЯ ПАЦІЕНТІВ ПРИ НЕТИПОВИХ АНАТОМІЧНИХ І ФУНКЦОНАЛЬНИХ СТАНАХ ПІС.Я РАДИКАЛЬНИХ ОРГАНОЗБЕРІГАЛЬНИХ ОПЕРАЦЙ ІЗ ПРИВОДУ НЕПУХЛИННИХ ЗАХВОРЮВАНЬ ТОВСТОӤ КИШКИ
}

\begin{abstract}
Мета роботи: показати сучасні можливості та шляхи забезпечення реабілітації пацієнтів після радикального хірургічного лікування непухлинних захворювань товстої кишки при наявних нетипових анатомічних і функціональних станах.

Матеріали і методи. Розроблено систему заходів хірургічної реабілітації, яку було використано у 32 пацієнтів із наявними нетиповими анатомічними і функціональними станами після радикальних органозберігальних операцій при непухлинних захворюваннях товстої кишки. Вони спрямовані на виконання достатньо радикальних, реконструктивно-відновних операцій, прогнозування та профілактику післяопераційних ускладнень, покращення функціональних результатів, зменшення частоти виникнення та ступеня вираженості тяжких форм діарейного та постколектомічного синдромів.

Результати досліджень та їх обговорення. У 2 (6,3 \%) пацієнтів виникли ускладнення, зумовлені виконанням реконструктивновідновного етапу хірургічного втручання. Вони призвели до необхідності виконання екстирпації кукси анального каналу, видалення ілеоендоанального анастомозу, формування довічної ілеостоми. У 30 (93,7 \%) пацієнтів отримано сприятливі функціональні результати, досягнуто значного рівня хірургічної та соціально-трудової реабілітації.

Значний рівень реабілітації оперованих пацієнтів було досягнуто за рахунок виконання достатньо радикальних та розроблених реконструктивно-відновних операцій, які попереджували рецидив захворювання, виникнення патологічних станів, зумовлених видаленням товстої кишки; прогнозування та цілеспрямованої профілактики тяжких післяопераційних ускладнень, етапного моніторингу стану оперованих пацієнтів.
\end{abstract}

Ключові слова: хірургічна реабілітація; непухлинні захворювання товстої кишки; реконструктивно-відновні операції.

В. М. МЕЛЬНИК, А. И. ПОЙДА, АБДУЛРАХМАН АБДУЛ КАДИР

Национальный медицинский университет имени А. А. Богомольца

\section{ХИРУРГИЧЕСКАЯ РЕАБИЛИТАЦИЯ ПАЦИЕНТОВ ПРИ НЕТИПИЧНЫХ АНАТОМИЧЕСКИХ И ФУНКЦИОНАЛЬНЫХ СОСТОЯНИЯХ ПОС.Е РАДИКАЛЬНЫХ ОРГАНОСОХРАНЯЮЩИХ ОПЕРАЦИЙ ПО ПОВОДУ НЕОПУХОЛЕВЫХ ЗАБОЛЕВАНИЙ ТОЛСТОЙ КИШКИ}

Цель работы: показать современные возможности и пути обеспечения реабилитации пациентов после радикального хирургического лечения неопухолевых заболеваний толстой кишки при имеющихся нетипичных анатомических и функциональных состояниях.

Материалы и методы. Разработана система мероприятий хирургической реабилитации, которая была использована у 32 пациентов с имеющимися нетипичными анатомическими и функциональными состояниями после радикальных органосохраняющих операций при неопухолевых заболеваниях толстой кишки. Они направлены на выполнение достаточно 


\section{ОРИГІНАЛЬНІ ДОСЛІДЖЕННЯ}

радикальных, реконструктивно-восстановительных операций, прогнозирование и профилактику послеоперационных осложнений, улучшение функциональных результатов, уменьшение частоты и степени выраженности тяжелых форм диарейного и постколектомичного синдромов.

Результаты исследований и их обсуждение. У 2 (6,3 \%) пациентов возникли осложнения, обусловленные выполнением реконструктивно-восстановительного этапа хирургического вмешательства. Они привели к необходимости выполнения экстирпации культи анального канала, удаления илеоэндоанального анастомоза, формирования пожизненной илеостомы. У 30 (93,7 \%) пациентов получены благоприятные функциональные результаты, достигнуто значительное улучшение уровня хирургической и социально-трудовой реабилитации.

Значительный уровень реабилитации оперированных пациентов было достигнуто за счет выполнения достаточно радикальных и разработанных реконструктивно-восстановительных операций, которые предупреждали рецидив заболевания, возникновение патологических состояний, обусловленных удалением толстой кишки; прогнозирования и целенаправленной профилактики тяжелых послеоперационных осложнений, этапного мониторинга состояния оперированных пациентов.

Ключевые слова: хирургическая реабилитация; неопухолевое заболевание толстой кишки; реконструктивно-восстановительные операции. 